\title{
Atorvastatin and Aspirin as Adjuvant Therapy in Patients with SARS-CoV-2 Infection: A structured summary of a study protocol for a randomised controlled trial
}

Nirmal Ghati ${ }^{1}$, Ambuj Roy ${ }^{1}$, Sushma Bhatnagar ${ }^{2}$, Sumit Bhati ${ }^{1}$, Sudha Bhushan ${ }^{1}$, Manjit Mahendran', Abhishek Thakur ${ }^{1}$, Pawan Tiwari ${ }^{3}$, Tanima Dwivedi ${ }^{4}$, Kalaivani Mani ${ }^{5}$, Ritu Gupta ${ }^{6}$, Anant Mohan ${ }^{3}$, Rakesh Garg ${ }^{2}$, Anita Saxena ${ }^{1}$, Randeep Guleria ${ }^{3}$ and Siddharthan Deepti ${ }^{1 *}$ (D)

\begin{abstract}
Objectives: To assess the impact of adding statin (atorvastatin) and/or aspirin on clinical deterioration in patients infected with SARS-CoV-2 who require hospitalisation. The safety of these drugs in COVID-19 patients will also be evaluated.

Trial design: This is a single-centre, prospective, four-arm parallel design, open-label, randomized control trial.

Participants: The study will be conducted at National Cancer Institute (NCl), Jhajjar, Haryana, which is a part of All India Institute of Medical Sciences (AlIMS), New Delhi, and has been converted into a dedicated COVID-19 management centre since the outbreak of the pandemic. All RT-PCR confirmed cases of SARS-CoV-2 infection with age $\geq 40$ years and $<75$ years requiring hospital admission (patients with WHO clinical improvement ordinal score 3 to 5) will be included in the trial. Written informed consent will be taken for all recruited patients. Patients with a critical illness (WHO clinical improvement ordinal score > 5), documented significant liver disease/dysfunction (aspartate transaminase [AST] / alanine aminotransferase [ALT] > 240), myopathy and rhabdomyolysis (creatine phosphokinase $[\mathrm{CPK}]>5 \mathrm{x}$ normal), allergy or intolerance to statins or aspirin, prior statin or aspirin use within 30 days, history of active gastrointestinal bleeding in past three months, coagulopathy, thrombocytopenia (platelet count $<100000 / \mathrm{dl}$ ), pregnancy, active breastfeeding, or inability to take oral or nasogastric medications will be excluded. Patients refusing to give written consent and taking drugs that are known to have a significant drug interaction with statin or aspirin [including cyclosporine, HIV protease inhibitors, hepatitis C protease inhibitor, telaprevir, fibric acid derivatives (gemfibrozil), niacin, azole antifungals (itraconazole, ketoconazole), clarithromycin and colchicine] will also be excluded from the trial.

(Continued on next page)
\end{abstract}

\footnotetext{
* Correspondence: deeptikailath@gmail.com

'Department of Cardiology, All India Institute of Medical Sciences (AllMS), Ansari Nagar East, New Delhi 110029, India

Full list of author information is available at the end of the article
}

(c) The Author(s). 2020 Open Access This article is licensed under a Creative Commons Attribution 4.0 International License, which permits use, sharing, adaptation, distribution and reproduction in any medium or format, as long as you give appropriate credit to the original author(s) and the source, provide a link to the Creative Commons licence, and indicate if changes were made. The images or other third party material in this article are included in the article's Creative Commons licence, unless indicated otherwise in a credit line to the material. If material is not included in the article's Creative Commons licence and your intended use is not permitted by statutory regulation or exceeds the permitted use, you will need to obtain permission directly from the copyright holder. To view a copy of this licence, visit http://creativecommons.org/licenses/by/4.0/ The Creative Commons Public Domain Dedication waiver (http://creativecommons.org/publicdomain/zero/1.0/) applies to the data made available in this article, unless otherwise stated in a credit line to the data. 
(Continued from previous page)

Intervention and comparator: In this study, the benefit and safety of atorvastatin (statin) and/or aspirin as adjuvant therapy will be compared with the control group receiving usual care for management of COVID-19. Atorvastatin will be prescribed as $40 \mathrm{mg}$ oral tablets once daily for ten days or until discharge, whichever is earlier. The dose of aspirin will be 75 mg once daily for ten days or until discharge, whichever is earlier. All other therapies will be administered according to the institute's COVID-19 treatment protocol and the treating physician's clinical judgment.

Main outcomes: All study participants will be prospectively followed up for ten days or until hospital discharge, whichever is longer for outcomes. The primary outcome will be clinical deterioration characterized by progression to WHO clinical improvement ordinal score $\geq 6$ (i.e., endotracheal intubation, non-invasive mechanical ventilation, pressor agents, renal replacement therapy, ECMO requirement, and mortality). The secondary outcomes will be change in serum inflammatory markers (C-reactive protein and Interleukin-6), Troponin I, and creatine phosphokinase (CPK) from time zero to 5th day of study enrolment or 7th day after symptom onset, whichever is later. Other clinical outcomes that will be assessed include progression to Acute Respiratory Distress Syndrome (ARDS), shock, ICU admission, length of ICU admission, length of hospital admission, and in-hospital mortality. Adverse drug effects like myalgia, myopathy, rhabdomyolysis, hepatotoxicity, and bleeding will also be examined in the trial to assess the safety of the interventions.

Randomisation: The study will use a four-arm parallel-group design. A computer-generated permuted block randomization with mixed block size will be used to randomize the participants in a 1:1:1:1 ratio to group A (atorvastatin with conventional therapy), group B (aspirin with conventional therapy), group C (aspirin + atorvastatin with conventional therapy), and group D (control; only conventional therapy).

Blinding (masking): The study will be an open-label trial.

Numbers to be randomised (sample size): As there is no existing study that has evaluated the role of aspirin and atorvastatin in COVID-19 patients, formal sample size calculation has not been done. Patients satisfying the inclusion and exclusion criteria will be recruited during six months of study period. Once the first 200 patients are included in each arm (i.e., total 800 patients), the final sample size calculation will be done on the basis of the interim analysis of the collected data.

Trial Status: The institutional ethical committee has approved the study protocol (Protocol version 3.0 [June 2020]).

Participant recruitment starting date: $28^{\text {th }}$ July 2020

Participant recruitment ending date: $27^{\text {th }}$ January 2021

Trial duration: 6 months

Trial registration: The trial has been prospectively registered in Clinical Trial Registry - India (ICMR- NIMS): Reference no. CTRI/2020/07/026791 (registered on 25 July 2020)].

Full protocol: The full protocol is attached as an additional file, accessible from the Trials website (Additional file 1). In the interest of expediting dissemination of this material, the familiar formatting has been eliminated; this Letter serves as a summary of the key elements of the full protocol.

Keywords: COVID-19, Randomised control trial, Protocol, Statin, Aspirin, Mortality

\section{Supplementary Information}

The online version contains supplementary material available at https://doi. org/10.1186/s13063-020-04840-y.

Additional file 1. Full Study Protocol.

\section{Acknowledgements}

Not applicable.

\section{Authors' contributions}

NG: Conceptualization, Methodology, Data curation, Visualization, WritingOriginal draft preparation, Writing - Review \& Editing; AR: Project Administration, Supervision, Resource, Conceptualization, Methodology, Writing- Original draft preparation; SuB: Project Administration, Supervision, Resource; SB, SB, MM, AT: Data curation, Methodology, Investigation; PT, TD: Methodology, Investigation; KM: Software, Formal Analysis, Validation; RiG, AM, RG, AS, RG: Supervision, Resources; SD: Project Administration,
Supervision, Resource, Conceptualization, Methodology, Investigation, Data curation, Visualization, Writing- Original draft preparation, Writing - Review \& Editing. The author(s) read and approved the final manuscript.

\section{Funding}

Nil.

\section{Availability of data and materials}

The final trial data will be available from the author on reasonable request (Email address of corresponding author is deeptikailath@gmail.com).

\section{Ethics approval and consent to participate}

The trial has received ethical approval from the institutional ethical committee (Ref. No. IEC-675/03.07.2020, RP-49/2020) on $16^{\text {th }}$ July 2020.

Printed patient information sheet (written in native language) will be distributed and written consent will be obtained from each patient before recruitment and randomization. 


\section{Consent for publication}

Not applicable.

\section{Competing interests}

The authors declare that they have no competing interests.

\section{Author details}

'Department of Cardiology, All India Institute of Medical Sciences (AlIMS), Ansari Nagar East, New Delhi 110029, India. ${ }^{2}$ Department of

Onco-Anaesthesia, Dr. B.R.A Institute-Rotary Cancer Hospital, All India Institute of Medical Sciences (AllMS), New Delhi, India. ${ }^{3}$ Department of Pulmonary Medicine and Sleep Disorders, All India Institute of Medical Sciences (AlIMS), New Delhi, India. ${ }^{4}$ Department of Laboratory Medicine, National Cancer Institute (Jhajjar, Haryana), All India Institute of Medical Sciences (AlIMS), New Delhi, India. ${ }^{5}$ Department of Biostatistics, All India Institute of Medical Sciences (AllMS), New Delhi, India. ${ }^{6}$ Department of Laboratory Oncology, Dr. B.R.A Institute-Rotary Cancer Hospital, All India Institute of Medical Sciences (AllMS), New Delhi, India.

Received: 19 October 2020 Accepted: 22 October 2020

Published online: 30 October 2020

\section{Publisher's Note}

Springer Nature remains neutral with regard to jurisdictional claims in published maps and institutional affiliations.

Ready to submit your research? Choose BMC and benefit from:

- fast, convenient online submission

- thorough peer review by experienced researchers in your field

- rapid publication on acceptance

- support for research data, including large and complex data types

- gold Open Access which fosters wider collaboration and increased citations

- maximum visibility for your research: over $100 \mathrm{M}$ website views per year

At $\mathrm{BMC}$, research is always in progress.

Learn more biomedcentral.com/submissions 